\title{
Melanosis coli or ischaemic colitis? That is the question
}

\author{
Biagio Ricciuti, ${ }^{1}$ Maria Comasia Leone, ${ }^{1}$ Giulio Metro ${ }^{2}$
}

${ }^{1}$ Department of Internal Medicine and Oncological Science, Santa Maria della Misericordia Hospital, Perugia, Italy

${ }^{2}$ Department of Medical Oncology, Santa Maria della Misericordia Hospital, Perugia, Italy

\section{Correspondence to}

Dr Biagio Ricciuti, biagio.ricciuti@gmail.com

Accepted 24 August 2015

\section{DESCRIPTION}

In June 2015, an 83-year-old man presented to the emergency department of Santa Maria della Misericordia Hospital in Perugia, Italy, with abdominal pain, bloating, worsening of chronic constipation and rectal bleeding. The physical examination at our department did not reveal abnormal findings, and laboratory investigation turned out negative. Consequently, the patient underwent an immediate colonoscopy, which unveiled the presence of congested and prolapsing internal haemorrhoids and an uneven brown to black staining of the colonic mucosa, apparently associated with scattered ulcers (figure 1). The endoscopic exploration was subsequently interrupted for precautionary reasons, suspecting an ischaemic colitis. However, multiple biopsies were randomly performed.
Surprisingly, there was no evidence of bowel ischaemia on histopathological examination, which conversely revealed an increase in the number macrophages filled with brown-coloured pigment granules in the lamina propria and muscularis mucosa, thus confirming the diagnosis of melanosis coli (figure 2). The patient's medical history was relevant for consumption of anthraquinonecontaining laxatives for 10 years.

Melanosis coli is an unusual brownish discolouration of the colonic mucosa, and detected on endoscopy or histopathological examination. This condition often develops within 5 months of anthraquinone-based laxative use (aloe, cascara sagrada, frangula, senna, rhubarb), and is widely recognised to be benign and reversible within 6-12 months of stopping laxatives. ${ }^{1}$ Although early studies reported potential mutagenic effects
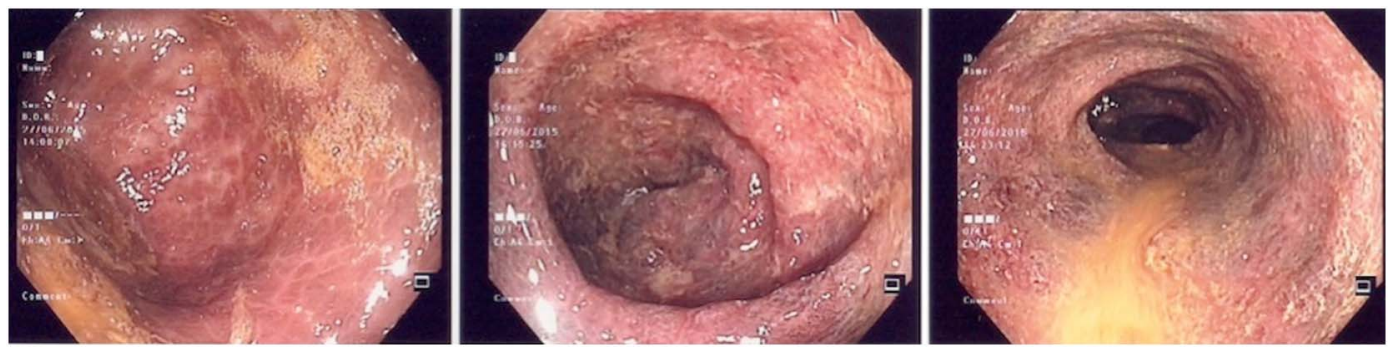

Figure 1 Colonoscopy revealing a diffuse dark brown pigmentation of colonic mucosa, which is consistent with the presence of melanosis coli.

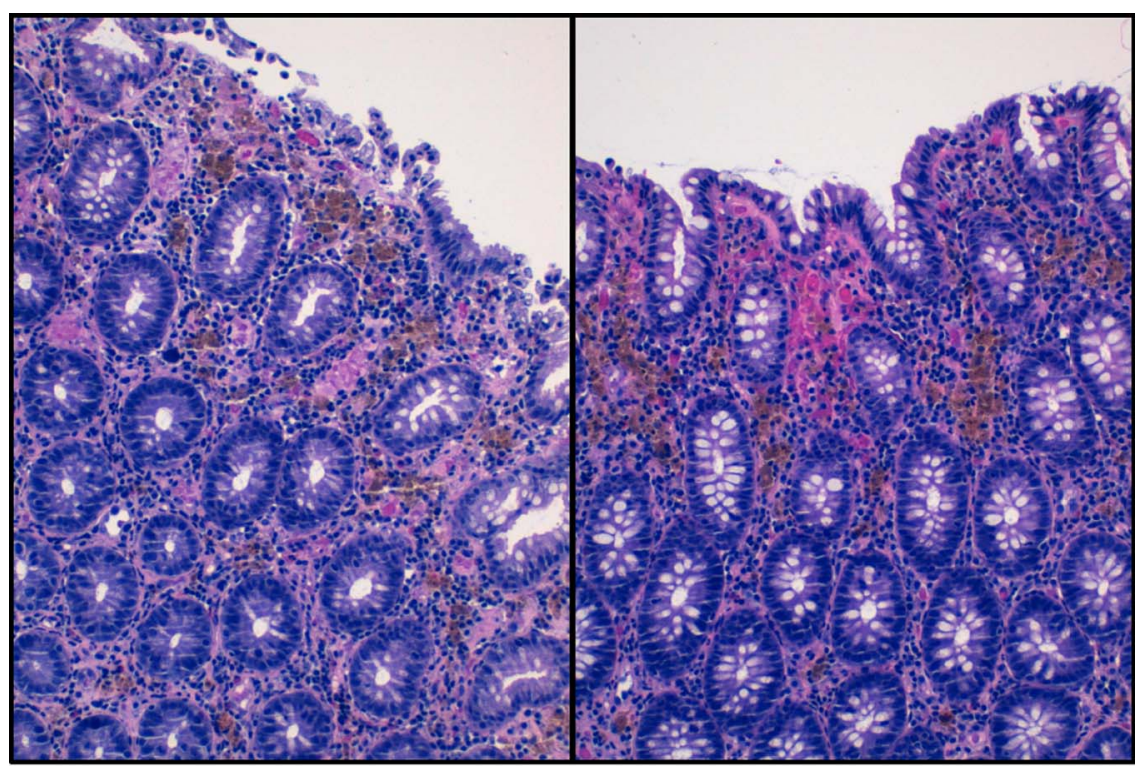

Figure 2 Photomicrograph showing typical macrophages filled with brown coloured pigment granules in the lamina propria and muscularis mucosa. 
for some anthranoid laxatives in vitro and in vivo models, recent data from large-scale retrospective, prospective and experimental studies, did not demonstrate any increased cancer risk. Of note, the apparent increase in the incidence of adenomas in patients with melanosis coli is due to easier detection of small adenomas against the dark staining of the colonic mucosa. ${ }^{1}$

Anthranoid-based laxatives impair colonic epithelial cell absorption, secretion and motility, leading to cell loss and shortening of mucosal crypts. As a consequence, damaged or apoptotic epithelial cells are engulfed by macrophages, where intracellular digestion results in residual lipofuscin bodies, which are responsible for the characteristic colour of the colonic mucosa. ${ }^{1}{ }^{2}$ Following our diagnosis, laxative intake was immediately suspended and a fibre-diet programme was started for treating the patient's constipation. The rectal bleeding was attributed to the presence of congested and prolapsing internal haemorrhoids, as no other rectal bleeding sources were identified during the hospitalisation.

It should be emphasised that, occasionally, discriminating between melanosis coli and ischaemic colitis represents a real challenge, especially in cases of extensive melanosis coli. For instance, Chaudhary and colleagues recently reported a case of a 63-year-old woman who was admitted to the hospital with a diagnosis of ischaemic colitis and underwent a subtotal colectomy with an end ileostomy. Later, the histopathological examination ruled out bowel ischaemia and revealed an extensive melanosis coli with pericolonic lymph node involvement. ${ }^{3}$
This report underlines the importance of melanosis coli in clinical practice, as it may mimic ischaemic colitis and must therefore be considered as a differential diagnosis.

\section{Learning points}

- Melanosis coli is a brownish discolouration of the colon mucosa caused by the accumulation of pigment in macrophages within the lamina propria.

- Melanosis coli often develops within 5 months of anthraquinone-based laxative use and is widely recognised to be benign and reversible within 6-12 months of stopping laxatives.

- Occasionally, extensive melanosis coli can mimic ischaemic colitis and clinicians must keep this in mind for a proper differential diagnosis.

Competing interests None declared.

Patient consent Obtained.

Provenance and peer review Not commissioned; externally peer reviewed.

\section{REFERENCES}

1 Kew S-T. Melanosis coli. IeJSME 2012;6(Suppl 1):S53-60.

2 Freeman HJ. "Melanosis" in the small and large intestine. World J Gastroenterol 2008;14:4296-9.

3 Chaudhary B, Sharma $H$, Nadeem M, et al. Ischemic colitis or melanosis coli: a case report. World J Emerg Surg 2007;2:25.

Copyright 2015 BMJ Publishing Group. All rights reserved. For permission to reuse any of this content visit http://group.bmj.com/group/rights-licensing/permissions.

BMJ Case Report Fellows may re-use this article for personal use and teaching without any further permission.

Become a Fellow of BMJ Case Reports today and you can:

- Submit as many cases as you like

- Enjoy fast sympathetic peer review and rapid publication of accepted articles

- Access all the published articles

- Re-use any of the published material for personal use and teaching without further permission

For information on Institutional Fellowships contact consortiasales@bmjgroup.com

Visit casereports.bmj.com for more articles like this and to become a Fellow 